\title{
Coherence between 19th century sperm whale distributions and satellite-derived pigments in the tropical Pacific
}

\author{
Nathalie Jaquet ${ }^{1, *}$, Hal Whitehead ${ }^{1}$, Marlon Lewis ${ }^{2}$ \\ 'Department of Biology, Dalhousie University, Halifax, Nova Scotia, Canada B3H $4 \mathrm{~J} 1$ \\ ${ }^{2}$ Department of Oceanography, Dalhousie University, Halifax, Nova Scotia, Canada B3H 4J1
}

\begin{abstract}
It has often been suggested that, given their large food requirements, sperm whale Physeter macrocephalus distributions should reflect the distribution of productive ocean environments, and it seems therefore that chlorophyll concentration might be a good indicator of sperm whale distribution. To examine the existence of such a relationship, and to determine over which scales it occurs, sperm whale density was correlated with phytoplankton pigment concentration over a range of spatia] and temporal scales. Sperm whale distribution was determined using records of kills from 19th century Yankee whaling, and the distribution of pigment concentration from satellite colour observations averaged over an 8 yr interval. These measures were compared over scales of $220 \mathrm{~km}$ square to $1780 \mathrm{~km}$ square. The distribution of sperm whales in the temperate and tropical Pacific Ocean was associated with distributions of phytoplankton pigment over every spatial scale considered, and the coefficient of correlation increased with increasing spatial scale. However, a few exceptions to this scheme were found, implying that other factors could be of importance in some regions. This study confirmed the existence of a space lag and a time lag between a peak in chlorophyll concentration and a peak in sperm whale density. It also demonstrated that over large spatial scales, and when the data are averaged over large temporal scales, chlorophyll concentration is a good indicator of sperm whale distribution, and that over these scales ocean colour recorded from space could help predict areas of high or low sperm whale density
\end{abstract}

KEY WORDS: Sperm whale Distribution Spatial scale. Temporal lag Chlorophyll concentration Satellite imagery

\section{INTRODUCTION}

Sperm whales Physeter macrocephalus play an important role in the pelagic marine food chain. With an estimated population size of about 1 to 1.9 million worldwide (Kanwisher \& Ridgway 1983, Rice 1989) and a consumption rate on the order of $500 \mathrm{~kg}$ ind. ${ }^{-1}$ $\mathrm{d}^{-1}$ (Clarke et al. 1993), the annual intake of squid, the primary food source of sperm whales, is estimated to be about 150 to $300 \mathrm{Mt} \mathrm{yr}^{-1}$. By comparison, the total annual harvest of fish by humans is currently $101 \mathrm{Mt}$ (FAO Yearbook 1993). The impact of sperm whales on the marine productive capacity, particularly in the

\footnotetext{
·E-mail:njaquet@is2.dal.ca
}

open ocean, is therefore potentially strong where high concentrations of whales exist. Despite the potential importance of sperm whales in the marine food web, little is known of their ecology and distribution. Their expansive habitat limits our understanding of the distribution of sperm whales in relation to environmental variables over large spatial and temporal scales.

It has often been suggested that, given their large food requirements, sperm whale distributions should reflect the distribution of productive ocean environments (Townsend 1935, Caldwell et al. 1966, Bradford et al. 1991). Forsbergh \& Joseph (1964), Banse (1973) and Gulland (1974) noticed the striking correlation between areas of upwelling and the main sperm whaling grounds as shown on charts of 19th century sperm whale catches, although in none of these studies was 
the relationship quantified. Similarly, Smith \& Whitehead (1993) found that around the Galápagos Islands, sperm whales were more numerous and had greater feeding success west of Isla Isabella, where upwelling and enhanced phytoplankton concentrations are most prominent (Feldman et al. 1984). However, other studies have stressed the coincidence of sperm whale concentrations with convergence zones (Gaskin 1968, 1973, Berzin 1971, Volkov \& Moroz 1977, Viale 1991), and thus postulated that sperm whales occur in downwelling areas.

This apparent contradiction concerning the factors controlling sperm whale distribution may be attributed to the differences in spatial and temporal scales used in these studies (Jaquet 1996). In an extensive literature search, Schneider (1994) did not find a single paper describing the relationship between whales and their potential prey at 2 or more spatial scales. As the factors controlling sperm whale distribution are likely to be scale dependent (Jaquet \& Whitehead 1996), a wide range of spatial and temporal scales have to be investigated to assess the relationship between sperm whale distribution and primary productivity. In addition, as spatial scales are closely linked to temporal scales (the largest structures being usually the most permanent; Stommel 1963), the time scale of a predator-prey relationship needs also to be considered.

The purpose of this paper is therefore to investigate relationships between the distribution of sperm whales and areas of high chlorophyll concentration over a wide range of spatial scales, and to discuss the temporal resolution of these relationships. Such a study can outline the importance of chlorophyll concentration as a factor influencing sperm whale distribution. As there is no recent extensive data set on the distribution of groups of female sperm whales (modern whaling has been mainly concerned with males), the results of this study could also be extrapolated to give valuable information on the actual relationship between sperm whale density and primary productivity. Moreover, with easily accessible satellite images of ocean colour, the existence of an association between chlorophyll concentration and sperm whale density, and the knowledge of the scales involved, could help us predict patterns of sperm whale distribution.

\section{METHODS}

Sperm whale data. When considering a very wide range of spatial and temporal scales, sperm whale distribution is probably best described by catch and sighting data from the Yankee whaling industry, 1712 to 1925 (Best 1983, Mitchell 1983, Sherman 1983, Shuster 1983a, Whitehead \& Jaquet 1996). During this period, there were no restrictions on the hunt and no sanctuaries for the whales, so the whalers explored all oceans between $40^{\circ} \mathrm{S}$ and $40^{\circ} \mathrm{N}$ providing data over very wide spatial scales. Up to 565 ships cruised the oceans at any one time in search of sperm whales (Best 1983) and their habit of 'gamming' and sharing information about productive grounds made these whalers efficient exploiters of resources (Whitehead \& Hope 1991). Although whalers used primitive means of hunting whales, several hundred thousand sperm whales were killed during this period (Shuster 1983a), providing a very large data set on their distribution.

It has been estimated that a total of about 14000 voyages were made by the Yankee sperm whalers between 1761 and 1924 (Shuster 1983a), and that about $30 \%$ of the logbooks and private journals have survived (Sherman 1965). Maury (1852) and Townsend (1935) extracted a large amount of data from these logbooks, and their charts showing sperm whale distribution were used in the present study to evaluate the historical sperm whale distribution between $40^{\circ} \mathrm{N}$ and $40^{\circ} \mathrm{S}$ in the Pacific Ocean.

(a) The Maury charts: Maury (1852) analyzed pre1851 logbooks and compiled charts which give indications of effort in each area as well as kills and sightings. He divided the world into $5^{\circ}$ by $5^{\circ}$ squares, and for each square gave the total number of days spent by different vessels searching for whales during each calendar month, as well as the total number of sperm whales seen or killed during this month. The data therefore provides an indication of catch per unit effort.

(b) The Townsend charts. Townsend (1935) analyzed the logbooks of 744 vessels making 1665 voyages between 1761 and 1920 (mostly between 1820 and 1860). On each day that one or several sperm whales were killed, he plotted the position of the ship on a world chart. In total, he recorded the locations where 36908 sperm whales were taken. As he used different coloured marks for each 2-mo period (DecemberJanuary, February-March, April-May, June-July, August-September and October-November), the seasonality of the catches in different areas is clearly shown.

The charts give no indication of the whaling effort. Therefore, the absence of catches in certain regions may not mean that no whales were found there, but may simply reflect little or no effort. Also, to avold superimposing dots when several whales were killed at the same location, he plotted the dots beside one another, sacrificing accuracy for readability.

Whitehead \& Jaquet (1996) used a simulation model to examine the relationships between total catch by Yankee whalers in an area, total catch per unit effort, and the pre-whaling spatial whale distribution. Both total catch and total catch per unit effort were highly correlated with the initial distribution but total catch 
was always better correlated than total catch per unit effort. Therefore, as the Townsend charts are more accurate and take into account more whaling voyages, they were used to described sperm whale distribution in the present study. The Maury charts were only used to examine the differences in whaling effort over different parts of the Pacific Ocean.

Pigment data. To evaluate the distribution of sperm whales relative to surface pigment, satellite-derived measurements of ocean colour, which have given the first global view of the potential productivity of the oceans, are most appropriate (Feldman et al. 1989, Lewis 1989). The Coastal Zone Color Scanner (CZCS) onboard the NIMBUS-7 spacecraft was in operation from 1978 until 1986 (Brown et al. 1985, Lewis 1992, Yoder et al. 1993). The sensor made observations of the spectral distribution of radiance emitted from the ocean surface as a result of selective absorption and backscattering of sunlight by particles and dissolved compounds in the sea. In the open ocean, removed from terrestrial influences, phytoplankton and their immediate breakdown products are the primary agents responsible for variation in ocean color as seen by satellite. The satellite radiances can therefore be used to compute the concentration of phytoplankton. pigment in the upper ocean to an accuracy of $30 \%$ for these waters (Gordon et al. 1988). Because the sensor was operated sporadically, and because of its inability to penetrate cloud cover, coverage of the study region was not uniform in time or space. However, the data include over 26037 valid individual observations over the study region and result in a representative view of the variability in the productive potential of the temperate and tropical Pacific Ocean. Data were extracted from the historical archive (Feldman et al. 1989) and averaged spatially and temporally to match the finest scales resolved by the sperm whale distribution from Townsend (1935)

The estimated surface pigment concentrations define to first order the productive capability of the ocean environment (e.g. Eppley et al. 1985). The exact relationship between pigment concentration and local rates of primary productivity remains an active area of research, and in general requires further ancillary data (such as solar radiation fluxes and surface temperature), and the fixing of locally appropriate parameters (Platt \& Sathyendranath 1988, Morel 1991, Balch et al 1992, Longhurst et al. 1995). However, the simple relationship between surface pigment and productivity defined by Eppley et al. (1985) appears to be valid when applied to more recently acquired data (J Campbell pers. comm.), and hence we have chosen to use the satellite surface pigment concentration as a good index of the potential productivity of the upper ocean over the range of scales investigated here.
Wind data. It has been shown by simulation that Townsend's (1935) charts are a reliable source of information on sperm whale seasonal distribution only in areas where catch efficiency shows little seasonal variability (Whitehead \& Jaquet 1996). Catch efficiency in the Yankee fishery decreased when the mean monthly wind speed was above $25 \mathrm{~km}^{-1}$ (Kahn 1991, Whitehead \& Jaquet 1996, B. Kahn pers. comm.). Therefore, to investigate the relationship between sperm whale distribution and pigment concentration, only areas and months for which the mean monthly wind speed was below $25 \mathrm{~km} \mathrm{~h}^{-1}$ (Force 4 on the Beaufort scale) were used for this study. The wind speed data were extracted from the Marine Climatic Atlas of the World (Version 1.0, March 1992, Naval Oceanography Command Detachment, Asheville, NC 28801, USA).

Data analyses. The tropical and temperate Pacific (between the American coast and $140^{\circ} \mathrm{E}$, and between $40^{\circ} \mathrm{N}$ and $40^{\circ} \mathrm{S}$ ) was first divided into $2^{\circ}$ latitude by $2^{\circ}$ longitude $(220 \mathrm{~km}$ by $\sim 220 \mathrm{~km})$ squares. As the position of a Yankee whaling ship was generally assessed only once per day, and as the dots on the Townsend's (1935) charts were drawn one beside the other when their true positions overlapped, it was felt that any scale smaller than $220 \mathrm{~km}$ would be unreliable. For each square, the total number of whale kills marked on Townsend's (1935) charts was counted, and the mean annual pigment concentration was calculated using Coastal Zone Color Scanner (CZCS) data. To increase the spatial scale, squares were combined to form $4^{\circ}$ by $4^{\circ}$ squares $(440 \times \sim 440 \mathrm{~km}), 8^{\circ}$ by $8^{\circ}(890 \times \sim 890 \mathrm{~km})$ and $16^{\circ}$ by $16^{\circ}$ squares $(1780 \times$ $\sim 1780 \mathrm{~km}$ ). Similarly, the total number of whales killed in each square for each 2-mo period (February-March, April-May, June-July, August-September, OctoberNovember and December-January) was counted, and the mean pigment concentration for each square and for each bimonthly period was likewise determined.

It has been shown for several species of baleen whales that during breeding and/or calving season the whales are found in waters which are less productive but more suitable for breeding and/or calving (Gaskin 1982). If sperm whales follow a similar pattern, as the peak of the breeding and calving season occurs at different times in northern and southern hemispheres (Best et al. 1984), a high correlation between sperm whale density and chlorophyll concentration might be present in one hemisphere, in contrast to a low correlation in the other hemisphere during a breeding or calving season. Therefore, for every 2 -mo period, the data were also separated by hemisphere (northern hemisphere $=0^{\circ}$ to $40^{\circ} \mathrm{N}$; southern hemisphere $=0^{\circ}$ to $40^{\circ} \mathrm{S}$, and the number of whales killed in each square for each 2-mo period and for each hemisphere, as well as the mean pigment concentration for each square, period and hemisphere, was calculated. 


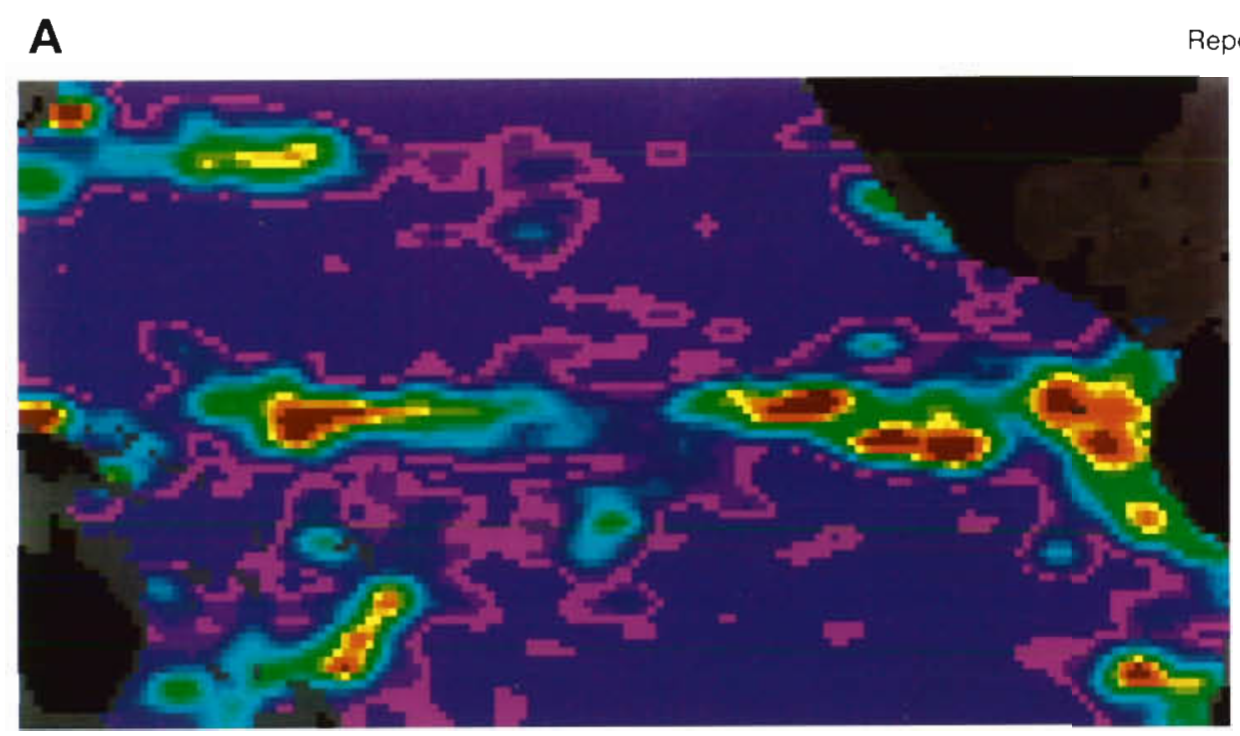

Reported whale kills

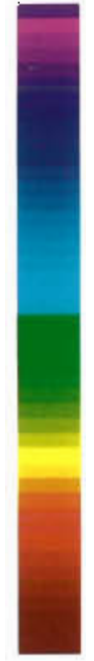

\section{0 \\ 5 \\ 10 \\ 15}

20

$>25$

B

Chlorophyll (mg m $\mathrm{m}^{-3}$ )
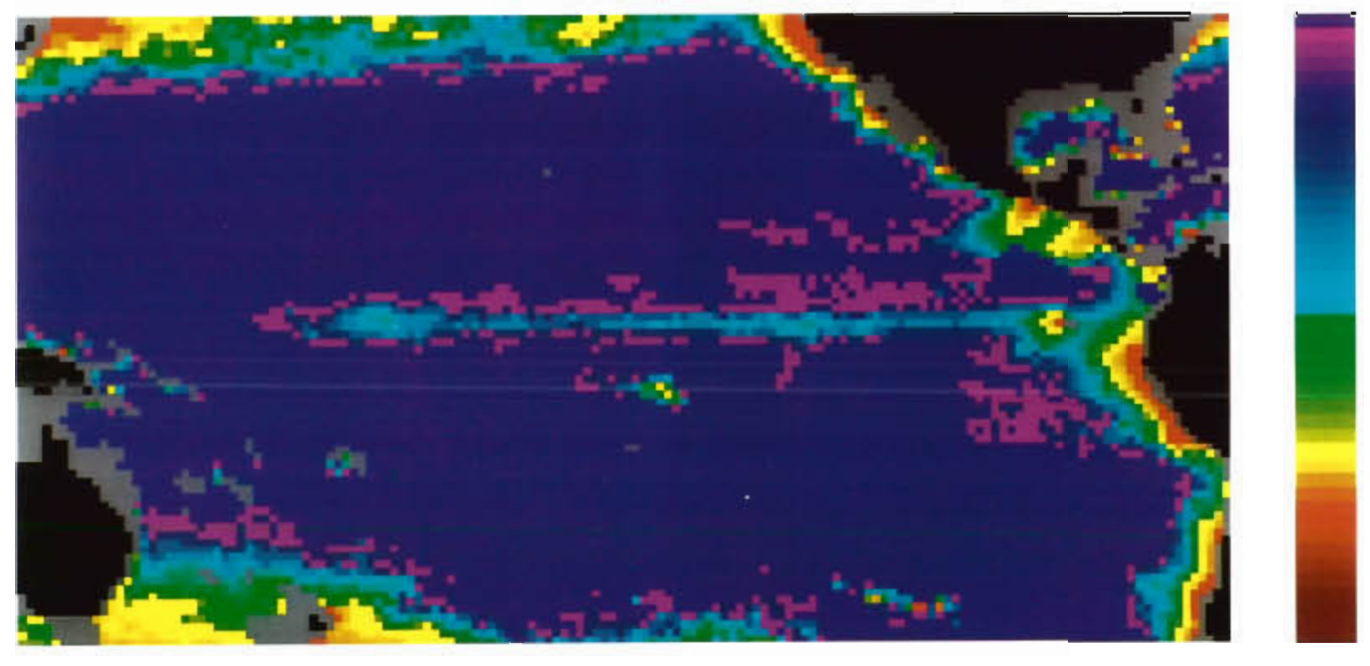

\section{C}

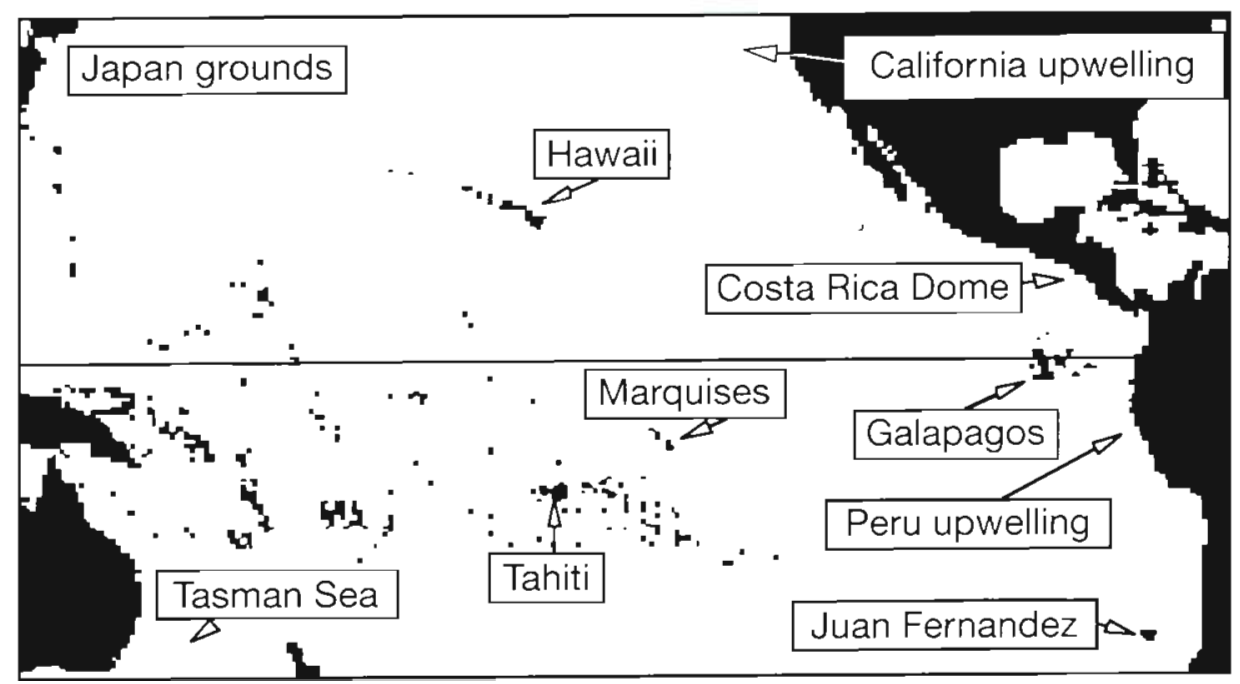

Fig. 1 (A) Sperm whale catches derived from 19 th century whaling records (B) Composite image of ocean phytoplankton pigment concentration derived from Coastal Zone Color Scanner data acquired between November 1978 and June 1986. (C) Location of the principal islands and main oceanographic features mentioned in the text 
As none of the variables were normally distributed, and as transformations (logarithm and square roots) succeeded in normalizing only the pigment concentrations over the largest spatial scales (KolmogorovSmirnov tests), non-parametric statistical methods were used to investigate the relationship between sperm whale distribution and chlorophyll concentration. Spearman coefficients of correlation $\left(r_{s}\right)$ were calculated between whale kills and chlorophyll concentrations at all spatial scales. Both variables showed some autocorrelation between squares, and transformations (value difference between 2 squares) failed to remove the autocorrelations (ACF plots) but reduced it to 1 to 2 lags. However, as we were more interested in finding patterns and consistencies than in rigorously testing hypotheses, we did not reduce the data set to remove the autocorrelations. Therefore, no significance test results are given here, but values of $r_{5}>0.25$ or $<-0.25$ were taken as indicators of a relationship.

\section{RESULTS}

For the whole study area, there were 2560 squares of $220 \times \sim 220 \mathrm{~km}$, and a total of 10475 dots on Townsend's (1935) charts, each representing the position where one or several sperm whales were taken in any one day (Fig. 1A). The overall mean surface pigment concentration was $0.1 \mathrm{mg} \mathrm{m}^{-3}$, but the variability was very high $\left(\mathrm{SD}=0.1 \mathrm{mg} \mathrm{m}^{-3}\right)$. The highest pigment values were found in the upwelling area off Peru where chlorophyll concentration often exceeded $0.6 \mathrm{mg} \mathrm{m}^{-3}$ Along the equator, the pigment concentration was high between $80^{\circ}$ and $100^{\circ} \mathrm{W}$ with many values between 0.2 and $0.5 \mathrm{mg} \mathrm{m}^{-3}$; from $100^{\circ} \mathrm{W}$ to the date line, the chlorophyll values were around $0.1 \mathrm{mg} \mathrm{m}^{-3}$; and lowest values, from 0.05 to $0.1 \mathrm{mg} \mathrm{m}^{-3}$, were found in the western Pacific. The Costa Rica Dome, some areas in the Japan grounds, the California upwelling and the Tasman Sea were also characterized by high values of pigment (Fig. 1B, C).

The Spearman correlation coefficients between overall, time-averaged sperm whale kills and pigment concentrations are substantially positive over every spatial scale (Fig. 2A). The coefficient of correlation increases with increasing spatial scale up to $890 \times \sim 890 \mathrm{~km}$ and then decreases slightly, suggesting that the maximum correlation between sperm whale catches and pigment concentration occurred at a spatial scale of approximately $900 \mathrm{~km}$ by $900 \mathrm{~km}$ (Fig. 2A).

These analyses indicate that, at least in the Pacific, and averaged over a large temporal scale, sperm whales were generally found in areas of high chlorophyll concentration. However, some areas, like those off Tahiti, are characterized by a low productivity (pig- ment concentrations $<0.05 \mathrm{mg} \mathrm{m}^{-3}$ ) but still support a rather high catch of whales (Fig. 1). Also, both the Costa Rica Dome and the Californian upwelling are known for their high productivity but only very few sperm whales were ever killed in these areas (Fig. 1). The Maury charts show that much effort was expended in Polynesia: in the four $5^{\circ} / 5^{\circ}$ squares comprising Tahiti and the Marquises, a mean of $564 \mathrm{~d}$ were spent searching for sperm whales in each square. On the other hand $301 \mathrm{~d}$ were spent in the $5^{\circ} / 5^{\circ}$ square of
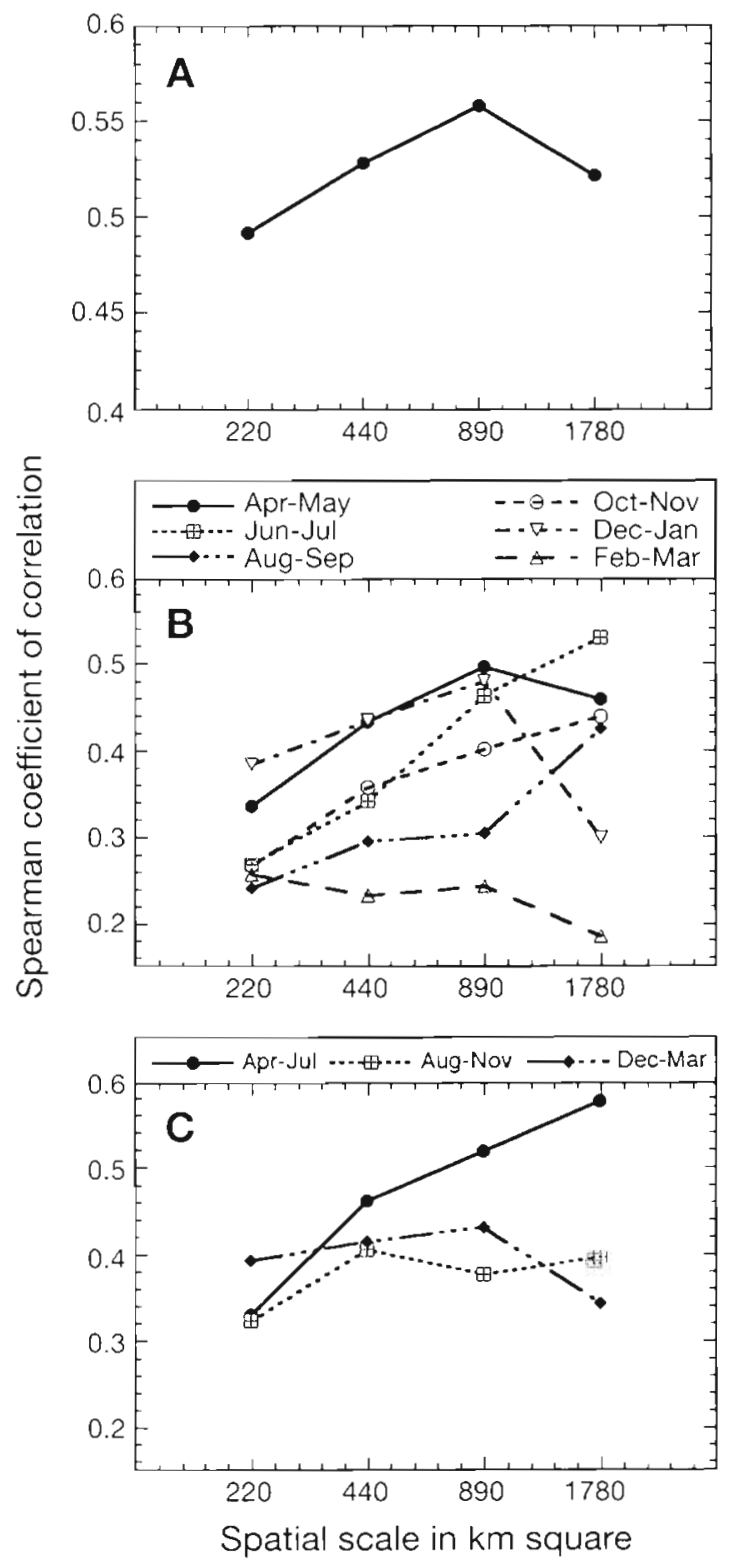

Fig. 2. Spearman coefficient of correlation between sperm whale kills and chlorophyll concentration over spatial scales ranging from $220 \mathrm{~km} \times-220 \mathrm{~km}$ to $1780 \mathrm{~km} \times \sim 1780 \mathrm{~km}$. (A) The data were averaged over 12 -mo periods. (B) The data were averaged over 2 -mo seasonal periods. (C) The data were averaged over 4 -mo seasonal periods 
the Costa Rica Dome and a mean of only $150 \mathrm{~d}$ in the 4 squares of $f$ California.

For spatial scales greater than $220 \times \sim 220 \mathrm{~km}$, timeresolved sperm whale catches and pigment concentration also show a substantial positive correlation for most 2-mo periods (Fig. 2B). The correlation coefficients are low for a spatial scale of $220 \mathrm{~km} \times \sim 220 \mathrm{~km}$, but generally increase with increasing spatial scale similarly to those for the annual mean (cf. Fig. 2A). At all spatial scales, the values of $r_{s}$ are generally higher for 4 -mo periods than for 2-mo periods, but the pattern is very similar (Fig 2C).

Fig. 3 shows the Spearman correlations between sperm whale kills and pigment concentration when each hemisphere is treated separately. To avoid confusion, only the spatial scale of $890 \times \sim 890 \mathrm{~km}$ is presented on this figure as it was the scale at which the correlation between sperm whale density and primary productivity was maximum; it is therefore the scale at which there is the greatest likelihood of observing differences in the values of $r_{5}$ due to breeding and/or calving requirements. This figure shows a high seasonal variability in the correlation between sperm whale catches and chlorophyll concentration, but for both hemispheres, there is not a lower correlation during the periods corresponding to the peak of the breeding and calving season than for other periods of the year.

\section{Evaluation of biases}

As the number of observations necessarily decreases with increasing spatial scale, the increase of $r_{s}$ could

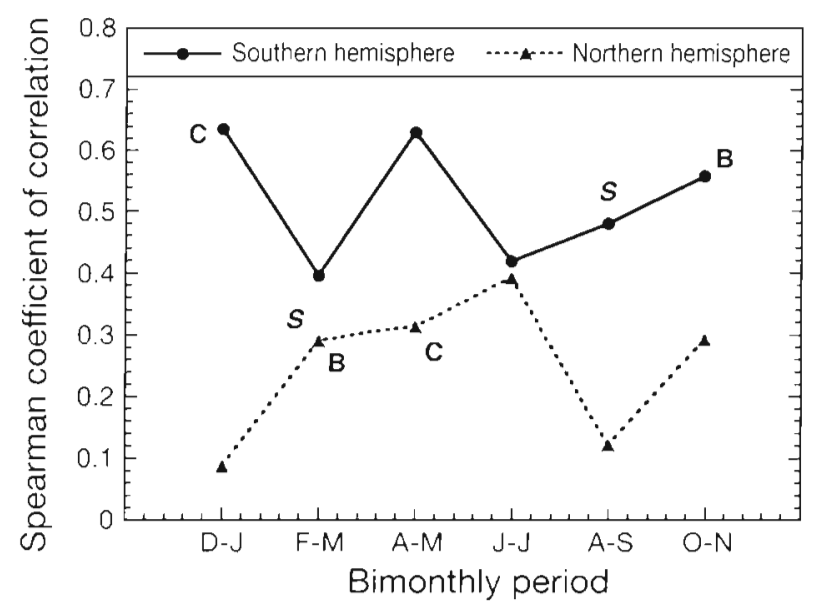

Fig. 3. Spearman coefficient of correlation between sperm whale kills and chlorophyll concentration for each hemisphere and for each 2-mo period. B: peak of the breeding season; $C$ : peak of the calving season; $S$ : peak of the squid spawning season (Caldwell et al. 1966, Best et al. 1984, O'Dor 1992) simply reflect a relationship with the number of observations. To test this possibility, a bootstrap method was used, where files of respectively $50,100,150,200,300$, $500,700,900,1100$ and 1300 observations were randomly extracted from the largest file (annual mean, spatial scale $220 \mathrm{~km} \times \sim 220 \mathrm{~km}$ ), and a Spearman correlation coefficient between pigment concentration and sperm whale catches was calculated for each of them. This revealed no increase of $r_{s}$ with decreasing number of observations and no particular pattern.

Stronger correlations at larger scales could also be the result of the smoothing of high frequency variance. Because of stochastic effects, smaller numbers of kills per square at smaller spatial scales are not as good a measure of true whale abundance as are the larger numbers found at larger spatial scales. To test for this possible bias, we replaced each whale count by a randomly chosen count from the Poisson distribution whose mean was the original count, and recalculated a Spearman coefficient of correlation between sperm whale kills and pigment concentration. Ten such simulations were carried out at each spatial scale. The Spearman correlation coefficient was biased downwards by 0.013 (standard error $=0.0021$ ) at the $220 \mathrm{~km}$ scale, but there was no discernible bias $(<0.01)$ at larger scales, suggesting again that the increase of $r_{s}$ with increasing spatial scale is a real phenomenon.

Finally, to test how sensitive the pattern observed on Fig. $2 \mathrm{~A}$ was to the location of the blocks, all the blocks were shifted by $220 \mathrm{~km}$ and a Spearman coefficient of correlation was calculated for the 3 larger spatial scales. We then shifted all the blocks by $440 \mathrm{~km}$ and by $890 \mathrm{~km}$ and recalculated a Spearman coefficient of correlation for the relevant spatial scales. In every case we observed the same general pattern of increasing $r_{s}$ with increasing spatial scale and only minor changes in $r_{s}( \pm 0.01$ to 0.04$)$ However, when the blocks were shifted, we did not find a diminution of $r_{s}$ at the largest spatial scale $(1780 \mathrm{~km})$, suggesting that the peak observed on Fig. $2 \mathrm{~A}$ at the $900 \mathrm{~km}$ spatial scale may depend on the blocks' location.

Therefore it was concluded that the increase of $r_{s}$ with increasing spatial scale was not a methodological artifact, although the drop at $1780 \mathrm{~km}$ may not reflect reality.

\section{DISCUSSION}

This study shows that, over large spatial and temporal scales, sperm whales are found in waters with higher chlorophyll concentration than adjacent waters, and that the coefficient of correlation between sperm whale catches and phytoplankton density generally increases with increasing spatial scale. Increasing 
coefficients of correlation between the distribution of a predator and the distribution of its prey with spatial scale have been observed in many studies involving marine birds and fish or zooplankton (Schneider 1994). For example, in studying the distribution of macaroni penguins Eudyptes chrysolophus and Antarctic krill Euphausia superba, Hunt et al. (1992) found an increase in $r_{5}$ from 0.11 to 0.80 at spatial scales ranging from $2 \mathrm{~km}$ to $470 \mathrm{~km}$. Patterns like the one shown on Fig. 2A have also been observed in other studies: the correlation between Antarctic fur seals Arctocephalus gazella and Antarctic krill shows an increase only until a spatial scale of $52 \mathrm{~km}$ and a decrease thereafter (Hunt et al. 1992). However, in all of these studies, the spatial scale of the correlations was much smaller than that found for sperm whales.

There are several exceptions to the general relationship between sperm whale distribution and pigment density, and neither the low density of whales in the California upwelling and in the Costa Rica Dome nor the high catches around Tahiti and around the Juan Fernandez Islands are consistent with chlorophyll concentrations. These anomalies can partly be explained by the uneven amount of effort expended in different areas of the Pacific, as the whalers were constrained by the weather and by the need to resupply once or twice a year. A fair wind was a necessity for these vessels to sail; B. Kahn (pers. comm.) estimated that the maximum efficiency in catching whales occurred at a wind strength of 10 to $32 \mathrm{~km} \mathrm{~h}^{-1}$ (Force 2 to 5 on the Beaufort scale), and in an area, catching efficiency decreased substantially when the mean monthly wind strength was above $25 \mathrm{~km} \mathrm{~h}^{-1}$ (Whitehead \& Jaquet 1996). However, the California upwelling and the Costa Rica Dome are both characterized by favorable winds during most of the year, and thus the low sperm whale catches cannot be explained by weather constraints.

During a typical voyage through the Pacific, the whalers usually sailed north along the west coast of South America, followed the equator pushed by the trade winds, went south to Tahiti to resupply, sailed back to the equator and followed it west before sailing north to the Japan Grounds in summer (Mitchell 1983). During the boreal winter, the whalers usually returned to the equator via Hawail. This circuit was sailed several times until the ship had been filled with oil. On their way home, the whalers often sailed through Tahiti, then south to meet the westerlies before going around Cape Horn (Mitchell 1983). In the course of the 19 th century, whalers tended to explore grounds further and further west, and occasionally to sail down the west coast of North America (Starbuck 1878, Mitchell 1983, Shuster 1983b). Tahiti was therefore a very popular stop for the Yankee whalers, and this explains the high amount of effort in the region. However, if sperm. whales were rare in the area, no amount of effort would permit high catches. Similarly, very little effort was expended along the California upwelling (a mean of only $150 \mathrm{~d}$ in each $5^{\circ} / 5^{\circ}$ square), but if whales had been found in high concentration, it is very likely that the course of the voyages would have been changed to sail through these grounds.

It has been shown that many species of muscular cephalopods spawn in unproductive tropical water; after hatching, the larvae drift with powerful western boundary currents to higher latitude feeding grounds and then the adults swim back to the spawning grounds a year later (Mann \& Lazier 1991, O'Dor 1992). The spawning grounds are thus characterized by low chlorophyll concentration but very high biomass and could be very profitable for squid-eating species like sperm whales. Therefore, a high density of sperm whales in apparently unproductive water could possibly be explained by a high density of spawning squids. However, except for a few species of commercially fished cephalopods, the location of the spawning grounds for most species remains unknown (O'Dor 1992). Moreover, depending on the region considered, 53 to $78 \%$ of sperm whale diet consists of ammoniacal squids (Clarke 1986), and very little is known of the life history of these cephalopods. It has often been suggested that this type of squid does not undertake extensive horizontal migrations, but, in growing older descends to cooler deeper waters (Roper \& Young 1975). Thus, to be able to assess whether sperm whales feed on spawning squids in unproductive water, much more would need to be known on meso- and bathypelagic cephalopod ecology and life cycles.

It seems therefore that, even if chlorophyll concentration is an important factor influencing sperm whale distribution over large spatial and temporal scales, other factors have to be considered in certain areas.

At spatial scales greater than $220 \mathrm{~km} \times \sim 220 \mathrm{~km}$, the Spearman coefficient of correlation between sperm whale kills and pigment concentration was substantially positive for every 2-mo period except FebruaryMarch, suggesting that throughout the year, sperm whales are found in areas of high chlorophyll concentration

The coefficient of correlation between sperm whale catches and phytoplankton concentration is in general lower for a 2-mo period than for a 4-mo period, and both are lower than those of a 12 -mo period. This is consistent with the existence of a time lag between a peak in chlorophyll concentration and a peak in sperm whale density. The present study cannot estimate the length of this time lag, as the data are averaged over long temporal scales ( 8 to $130 \mathrm{yr}$ ), and as peak time of upwelling is likely to vary between years. However, this study suggests the existence of a time lag of at 
least 4 mo. Sette (1955) estimated that a time lag of 75 to $150 \mathrm{~d}$ was required for the development of 3 trophic levels in a marine community, and Blackburn et al. (1970) suggested that the peak in density of primary carnivores (like some cephalopods or fishes) in equatorial regions lags behind the peak in chlorophyll concentration by about $4 \mathrm{mo}$. Therefore, over very short time periods, there may be no correlation between sperm whale density and pigment concentration. This is confirmed by the work of Jaquet \& Whitehead (1996), who analyzed data from a survey around the South Pacific: when short time-scale data were used, there was no correlation between sperm whale distribution and phytoplankton concentration over all spatial scales considered (150 to $1200 \mathrm{~km}$ ). This is also consistent with what is expected in any predator-prey relationship: within areas the size of a whaling ground $(500$ to $2000 \mathrm{~km})$, the density of sperm whales should reflect long-term mean prey density, but not necessarily prey density within a given year or a given season (Heinemann et al. 1989). Similarly, Hunt (1990) and Piatt (1990) found that spatial association of birds with prey is episodic at small time scales but increases with increasing time resolution.

The increase of $I_{\mathrm{S}}$ with increasing spatial scales suggests that there is also a spatial lag between a peak in chlorophyll concentration and a peak in sperm whale catches. However, as the data are averaged over several years, and as it is likely that the exact location of upwelling (especially the equatorial upwelling) shifts slightly between years (Vinogradov 1981), it is not possible to assess the size of the space lag. Vinogradov (1981) showed that there is about 280 to $460 \mathrm{~km}$ between associated up- and downwelling phenomena. Therefore, while this study suggests that sperm whales are found in large areas $(\sim 900 \times \sim 900 \mathrm{~km}$ or larger $)$ characterized by high primary productivity, within these areas sperm whales could be more closely associated with downwelling phenomena than with the upwellings.

Unlike several species of baleen whale, sperm whales are not found in unproductive waters during the peak of the breeding and/or calving season. It has been postulated that the mysticete annual migrations evolved as a response to the need for warm water by newborn calves (Baker 1978), although this is controversial as many small odontocetes live and give birth at high latitudes (Evans 1990). Therefore, as female sperm whales stay all year round in waters warmer than $15^{\circ} \mathrm{C}$ (Rice 1989), it is not unexpected to find that they do not seem to change their distribution to satisfy breeding and/or calving requirements. Similarly, for both hemispheres, the lowest values of $r_{5}$ during 2 bimonthly periods cannot be attributed to the peak of the squid spawning season. However, too little is actually known of the life history of mesopelagic squid to rule out the possibility that sperm whales take advantage of the high cephalopod biomass occurring in spawning grounds at some times of the year

\section{CONCLUSION}

This study suggests that, when averaged over large temporal scales, sperm whales are generally found in broad areas $(-900 \mathrm{~km} \times-900 \mathrm{~km}$ or larger $)$ characterized by high concentrations of chlorophyll. It also emphazizes the scale dependence in the aggregative response of sperm whales to pigment concentration both on a spatial and a temporal scale. In addition, this study demonstrates the potential of Yankee whaling data for investigating the factors controlling sperm whale distribution. Satellite observations of ocean colour are therefore useful for predicting likely areas of high sperm whale density. However, remote sensing can only be used as an indicator of sperm whale distribution over large spatial and temporal scales, as there is no relationship over small scales. Moreover, some 'anomalies' in sperm whale distribution cannot be explained in terms of chlorophyll concentrations, implying that other factors (maybe squid spawning grounds) could be of significant importance in some regions.

Acknowledgements. We are very grateful to C. Parvati who extracted the data from the Coastal Zone Color Scanner, and to K. Fisher, who greatly helped us in producing the colour maps of sperm whale kills and pigment concentration. The manuscript was much improved by comments by $M$. Dillon, I. MacLaren, R. O'Dor and R. Scheibling and 3 anonymous reviewers. N. Jaquet was supported by the Izaak Walton Killam Memorial Scholarship, the Roche Research Foundation, the 'Société Académique Vaudoise', the 'Basler Stiftung für brologische Forschung', and the 'Fondation JanggenPoehn' Research by $M$. Lewis was supported by the Natural Sciences and Engineering Research Council and the Joint Global Ocean Flux Study.

\section{LITERATURE CITED}

Baker RR (1978) The evolutionary ecology of animal migration. Holmes and Meier, New York

Balch WM, Evans R, Brown J, Feldman G, McClain C, Esaias $W$ (1992) The remote sensing of ocean primary productivity: use of new data compilation to test satellite algorithms. J Geophys Res 97:2279

Banse K (1973) Global distribution of organic production in the oceans. In: English TS (ed) Ocean resources and public policy. University of Washington Press, Seattle, p 38-48

Berzin AA (1971) The sperm whale. Pischevaya Promyshlennost, Moscow (translation by lsrael Program for Scientufic Translations, Jerusalem)

Best PB (1983) Sperm whale stock assessments and the rele- 
vance of historical whaling records. Rep Int Whal Commn (Special Issue 5):41-55

Best PB, Canham PAS, MacLeod N (1984) Patterns of reproduction in sperm whales, Physcter macrocephalus. Rep Int Whal Commn (Special Issue 6):51-79

Blackburn M, Laurs RM, Owen RW, Zeitzschel B (1970) Seasonal and areal changes in standing stocks of phytoplankton, zooplankton and micronekton in the Eastern Tropical Pacific Mar Biol 7:14-31

Bradford JM, Cranfield HJ, Michael KP (1991) Phytoplankton biomass in relation to the surface hydrography of southern New Zealand and possible effects on the food chain. NZ J Mar Freshwat Res 25:133-144

Brown OB, Evans RH, Brown J, Gordon HR, Smith RC, Baker KS (1985) Phytoplankton blooming off the U.S. East Coast: a satellite description. Science 229:163-167

Caldwell KD. Caldwell MC. Rice DW (1966) Behavior of the sperm whale, Physeter catodon. In: Norris KS (ed) Whales, dolphins and porpoises. Unuv of Calif Press, Berkeley, p $677-717$

Clarke MR (1986) Cephalopods in the diet of odontocetes. In: Bryden MM. Harrison R (eds) Research on dolphins. Clarendon Press, Oxford, p 281-321

Clarke MR, Martins HR, Pascoe P (1993) The diet of sperm whales (Physeter macrocephalus) off the Azores. Phil Trans R Soc Lond B 339:67-82

Eppley RW, Stewart E, Abbott MR, Heyman U (1985) Estimated ocean primary production from satellite chlorophyll, introduction to regional differences and statistics for the Southern California Bight. J Plankton Res 7:57-70

Evans PGH (1990) The natural history of whales and dolphins. Facts on File, Oxford

FAO Yearbook (1993) Catches and landings, Vol 76 UNESCO, Rome

Feldman G, Clark D, Halpern D (1984) Satellite color observations of the phytoplankton distribution in the eastern Equatorial Pacific during the 1982-1983 El Nino. Science 226:1069-1071

Feldman GC, Kuring N, Ng C, Esaias W, McClain C, Elrod J, Maynard N, Endres D, Evans R, Brown J, Walsh S, Carle M. Podesta G (1989) Ocean color: availability of the global data set. EOS 70:634

Forsbergh ED, Joseph J (1964) Biological production in the Eastern Tropical Pacific. Inter-Am Trop Tuna Comm Bull 8:479-527

Gaskin DE (1968) Analysis of sightings and catches of sperm whales (Physeter catodon) in the Cook Strait area of New Zealand in 1963-4. NZ J Mar Freshwat Res 2:260-272

Gaskin DE (1973) Sperm whales in the western South Pacific NZ J Mar Freshwat Res 7:1-20

Gaskin DE (1982) The ecology of whales and dolphins. Heineman Press, Portsmouth, NH

Gordon HR, Brown OB, Evans RH, Brown JW. Smith RC, Baker KS, Clark DK (1988) A semianalytic radiance model of ocean color. J Geophys Res 93:10909-10924

Gulland JA (1974) Distribution and abundance of whales in relation to basic productivity. In: Schevill WE (ed) The whale problem. Harvard University Press, Cambridge, MA, p 27-52

Heinemann D. Hunt GL, Everson I (1989) Relationships between the distribution of marine avian predators and their prey, Euphausia superba, in Bransfield Strait and southern Drake Passage, Antarctica Mar Ecol Prog Ser 58:3-16

Hunt GL (1990) The pelagic distribution of marine birds in a heterogeneous environment. Polar Res 8:43-54

Hunt GL, Heumemann D, Everson 1 (1992) Distribution and predator-prey interactions of macaroni penguins, Ant- arctic fur seals, and Antarctic krill near Bird-Island, South Georgia. Mar Ecol Prog Ser 86:15-30

Jaquet $N$ (1996) How spatial and temporal scales influence understanding of sperm whale distribution: a review. Mammal Rev 26(1):51-65

Jaquet N, Whitehead H (1996) Scale-dependent correlation of sperm whale distrabution with environmental features and productivity in the South Pacific. Mar Ecol Prog Ser 135:1-9

Kahn B (1991) The population biology and social organization of sperm whates (Physeter macrocephalus) off the Seychelles: indications of recent exploitation. MSc thesis, Dalhousie University, Halifax

Kanwisher JW, Ridgway SH (1983) The physiological ecology of whales and porpoises. Sci Am 248(6):110-121

Lewis MR (1989) The blooming oceans. New Sci 124:37-40

Lewis MR (1992) Satellite ocean color observations of global biogeochemical cycles. In: Falkowski PG, Woodhead AD (eds) Primary productivity and biogeochemical cycles in the sea. Plenum Press, New York, p 139-153

Longhurst A, Sathyendranath S, Platt T, Caverhill C (1995) An estimate of global primary production in the ocean from satellite radiometer data. J Plankton Res 17:1245-1271

Mann KH, Lazier JRN (1991) Dynamics of marine ecosystems. Blackwell, Oxford

Maury MF (1852) Wind and current charts. Whale sheets number 1 to 4 , series F. United States Hydrographical Office, Washington DC

Mitchell E (1983) Potential of whaling logbook data for studying aspects of social structure in the sperm whale, Physeter macrocephalus, with an example--the ship Mariner to the Pacific, 1836-1840. Rep Int Whal Commn (Special Issue 5):63-80

Morel A (1991) Light and marine photosynthesis: a spectral model with geochemical and climatological implications Prog Oceanogr 26:263

O'Dor R (1992) Big squids in big currents. S Afr J Mar Sci 12 : $225-235$

Piatt JF (1990) The aggregative responses of common murres and Atlantic puffins to schools of capelin. Stud Avian Biol $14: 36-51$

Platt $T$, Sathyendranath $S$ (1988) Oceanic primary production estimation by remote sensing at local and regional scales. Sciences 241:1613-1620

Rice DW (1989) Sperm whales (Physeter macrocephalus). In: Ridgway SH, Harrison R (eds) Handbook of marine mammals, Vol. 4. Academic Press, London, p 177-233

Roper CFE, Young RE (1975) Vertical distribution of pelagic cephalopods. Smithson Contrib Zool 209:1-51

Schneider DC (1994) Scale-dependent patterns and species interactions in marine nekton. In Giller P, Hildrew AG, Rafaelli D (eds) Aquatic ecology: scale, pattern and process. Blackwell Scientifıc Publications, Oxford, p 441-467

Sette OE (1955) Consideration of midocean fish production as related to oceanic circulatory systems. J Mar Res 14(4): 398-414

Sherman SC (1965) The voice of the whaleman, with an account of the Nicholson whaling collection. Providence Public Library, Providence, RI

Sherman SC (1983) The nature, possibilities, and limitations of whaling logbook data. Rep Int Whal Commn (Special Issue 5): $35-40$

Shuster GW (1983a) Proposed methodology for extracting sperm whale data from logbooks. Rep Int What Commn (Special Issue 5):57-62

Shuster GW (1983b) The Galápagos Islands: a preliminary study of the effects of sperm whaling on a specific whaling ground. Rep Int Whal Commn (Special Issue 5):81-82 
Smith SC, Whitehead H (1993) Variation in the feeding success and behaviour of Galápagos sperm whales (Physeter macrocephalus) as they relate to oceanographic conditions. Can J Zool 71:1991-1996

Starbuck A (1878) History of the Amencan whale fishery from its earliest inception to the year 1878. Rep US Commn Fish and Fisheries 1875-1876(4):1-779

Stommel HC (1963) The vaneties of oceanographic experience. Science 139:572-576

Townsend $\mathrm{CH}$ (1935) The distribution of certain whales as shown by logbook records of American whalerships. Zoologica $19(1): 1-50$

Viale D (1991) Une méthode synoptique de recherche des zones productives en mer détection simultanée des cétacés, des fronts thermiques et des biomasses sous-jacentes. Ann Inst Oceanogr, Paris 67(1):49-62

This article was submitted to the editor
Vinogradov ME (1981) Ecosystems of equatorial upwellings. In: Longhurst AR (ed) Analysis of marine ecosysterns. Academic Press, London, p 69-94

Volkov AF, Moroz IF (1977) Oceanological conditions of the distribution of Cetacea in the eastern tropical part of the Pacific Ocean. Rep Int Whal Commn 27:186-188

Whitehead H, Hope PL (1991) Sperm whalers off the Galápagos Islands and in the western North Pacific, 1830-1850: ideal free whalers? Ethol Sociobiol 12:147-161

Whitehead H, Jaquet N (1996) Are the charts of Maury and Townsend good indicators of sperm whale distribution and seasonality? Rep Int Whal Commn 46:643-647

Yoder JA, McClain CR, Feldman GC, Esaias WE (1993) Annual cycles of phytoplankton chlorophyll concentrations in the global ocean: a satellite view. Global Biogeochem Cycles $7: 181-193$

Manuscript first received: April 25, 1996

Revised version accepted: October 4, 1996 